\title{
Age Estimation of Qash Qooly Valley in Dokan Vicinity, North Iraq Using Exposure Age Determination Method
}

\author{
Varoujan K. Sissakian ${ }^{1}$, Nadhir Al-Ansari ${ }^{2}$ and Sven Knutsson ${ }^{2}$ \\ 1. Private consultant, Erbil 14006, Iraq \\ 2. Department of Civil Environmental and Natural Resources Engineering, Lulea University of Technology, Lulea 97187, Sweden
}

\begin{abstract}
Qash Qooly valley runs parallel to Pera Magroon, Sara and Surdash anticlines, almost in SE-NW trend, and merges with the Lesser Zab River $9 \mathrm{~km}$ southeast to Dokan town. Before its development, it was a large basin with width ranges between 2 3 km, which was filled during Pleistocene or may be Late Pliocene by different types of sediments. The presence of the calcrete on the top indicates a wet period that has lasted for a long time as indicated from the thickness of the calcrete and alluvial fan sediments. The age of Qash Qooly valley was estimated using the exposure age determination method. The type of the sediments, their thicknesses, and erosion intensity and sediments' dens dissection by rills were the main features used. This study concluded that the age of the basin is Pliocene-Late Pleistocene, whereas the valley started to be developed during uppermost Late Pleistocene and is still active in shifting its course.
\end{abstract}

Key words: Pleistocene, alluvial fans, piedmont, calcrete, active erosion.

\section{Introduction}

The studied area is located in Sulaimaniyah Governorate, Kurdistan Region, Iraq at Dokan vicinity, along Pera Magroon and Sara mountains (Fig. 1). Qash Qooly valley runs parallel to Surdash and Pera Magroon mountains in SE-NW trend. Ethnically, the area is located within Kurdistan region and populated by Kurdish people who are mainly engaged in cultivation activities.

Qash Qooly valley is not one of the largest valleys in Dokan and Sulaimaniyah vicinities, but it is one of the unique valleys that have very thick Quaternary sediments. It runs parallel to the southwestern limb of Pera Magroon and Surdash anticlines in SE-NW trend and its continuation, which runs parallel to the main regional trend of the anticlines. Although the left bank of the valley includes soft rock formations, Shiranish, Tanjero, Kolosh and Gercus, the thick unusual Quaternary sediments are developed on its right bank,

Corresponding author: Nadhir Al-Ansari, professor, research fields: water resources and environmental engineering. E-mail: nadhir.alansari@1tu.se. which include very hard rocks of Qamchuqa Formation that forms the carapace of Pera Magroon and Surdash mountains.

Despite the fact that many works dealt with the study area, none of the existing works have dealt with age estimation using exposure age determination method. The previous works have dealt with different geological aspects in the studies area:

- Hamasur [1] reported about a large landslide alongside Pera Magroon mountain. He estimated the weight of the slid mass to be 200 million $t$, and called it Qara Chattan rock slide;

- Hamza [2] compiled the geomorphological map of Iraq at scale of 1:1,000,000, but did not represent the Quaternary sediments in the studied area;

- Karim et al. [3] also reported about Qara Chattan rock slide and mentioned more details than Hamasur [1];

- Barwari et al. [4] compiled the Quaternary sediments map of Iraq, scale 1: 1,000,000, but did not represent the Quaternary sediments in the studied area; 


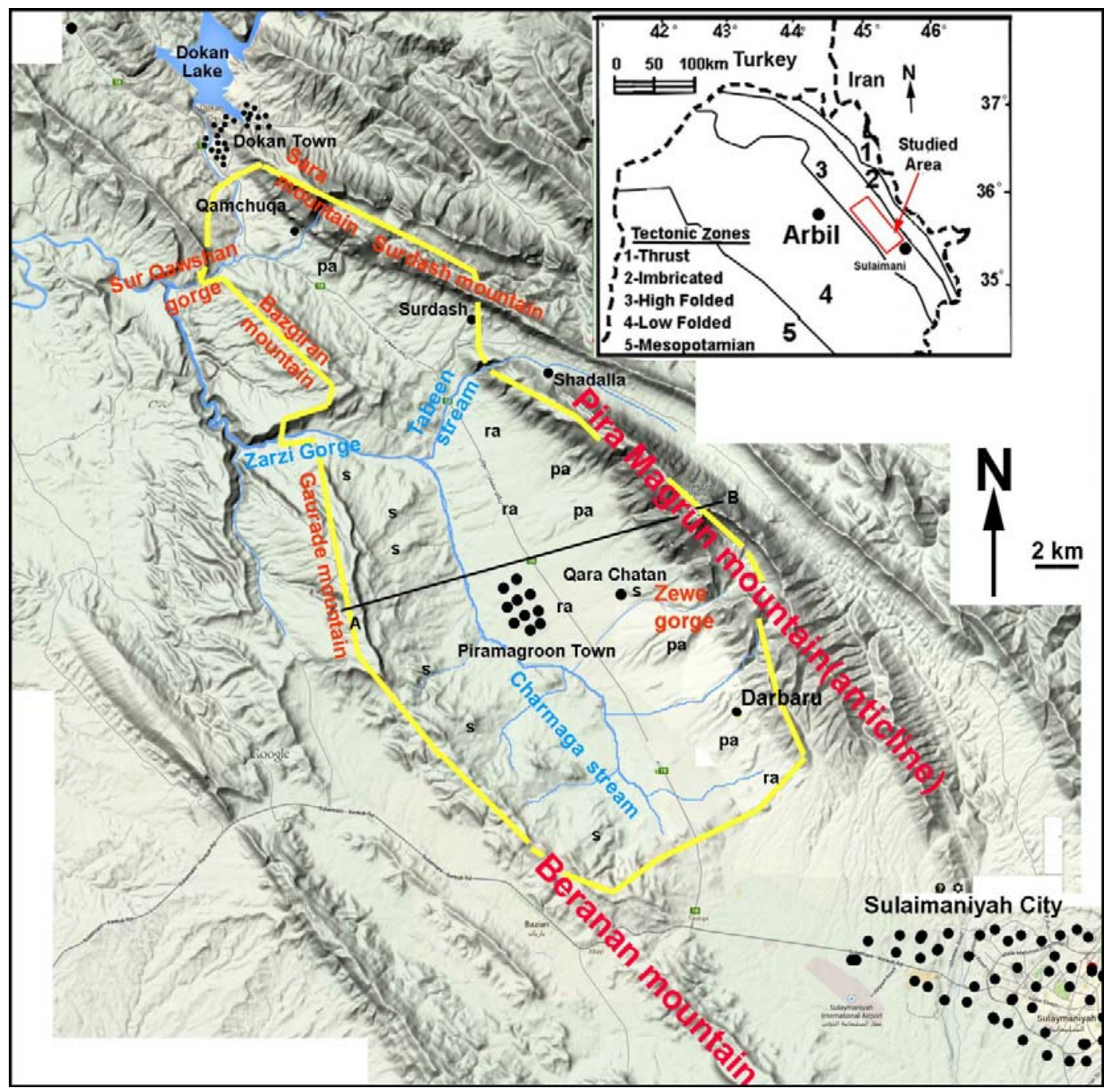

Fig. 1 Location map of the studied area.

- Sissakian and Fouad [5] compiled the geological map of Iraq at scale of 1:1,000,000, but did not represent the Quaternary sediments in the studied area;

- Sissakian and Fouad [6] compiled the geological map of Sulaimaniyah Quadrangle, scale 1:250,000, without presenting details of Quaternary sediments.

The aim of this study is to estimate the age of Qash Qooly valley, using exposure age determination method [7], as a typical valley including different Quaternary sediments, with different geomorphological features and landforms that can be used in exposure age determination method, which is used in this study successively.

\section{Tools Used and Method of Work}

To achieve the aim of this study, the following tools were used:

- geological maps, at scale of 1:100,000, 1:250,000 and 1:1,000,000;

- topographical maps, at scale of 1:100,000;

- Google Earth, DEM (digital elevation model) and satellite images;

- relevant published articles and reports.

The geological and topographical maps with the Google Earth, DEM and satellite images were used to recognize different Quaternary sediments and features.

Field work was carried out in August and October 2014 to acquire interesting data, like type of sediments, 
their description, thicknesses, and inclination of slopes. Many interesting and representative land forms and geomorphological units were photographed, too. Some structural data were also reviewed to elucidate the relation between the orientation of the valley and the present structural features.

\section{Geological Setting}

The geological aspects of the studied area are described hereinafter briefly based on Refs. [5, 6, 8].

\subsection{Geomorphology}

The most significant geomorphological features in the studied area are:

\subsubsection{Alluvial Depositional Units}

These are represented by: alluvial fans, pediments, calcrete, river terraces, infill valley sediments and flood plain sediments. They all are well developed with huge thicknesses that exceed $30 \mathrm{~m}$, and locally more than $50 \mathrm{~m}$, developed mainly along the

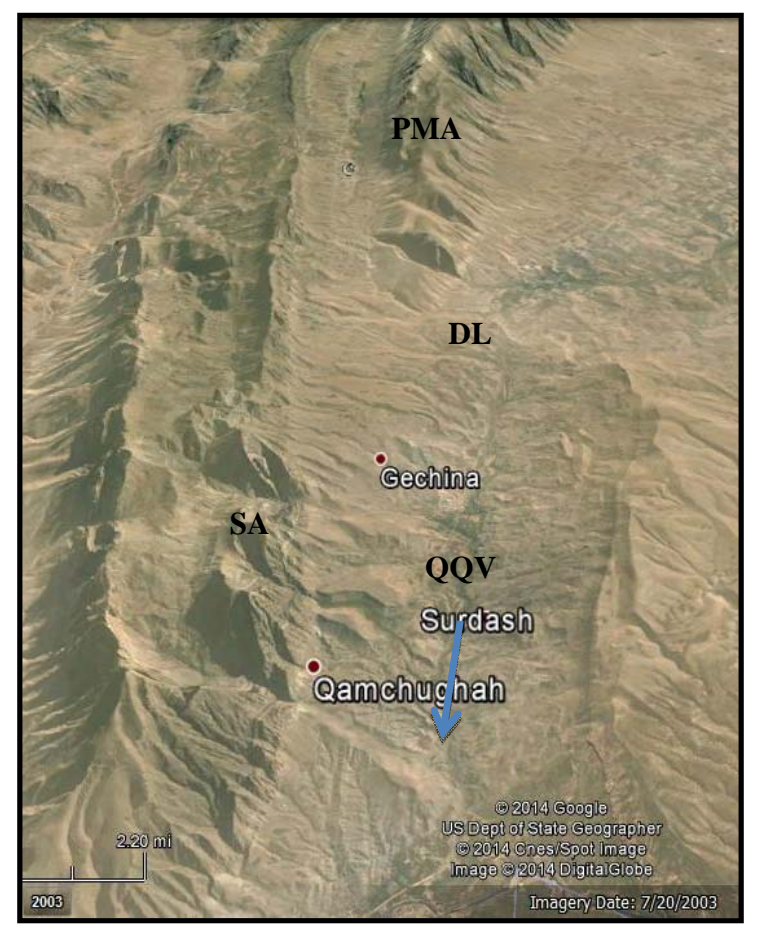

(a) southwestern limb of Pera Magroon, Sara and Surdash anticlines. The calcrete is the youngest within the Pleistocene sediments since it covers usually other types of sediments.

Alluvial fans are well developed everywhere in the studied area. The youngest alluvial fans are coalescent forming bajada (Fig. 2a), whereas the old fans are very large, with large parts eroded (Fig. 2b). The clasts are mainly derived from the Qamchuqa Formation, up to $2 \mathrm{~m}$ in size, but generally range in size from 15 45 cm in the apex part (Fig. 3a), and finer in the proximal parts, spherical in shape, rounded to well rounded, in the proximal part, whereas sub-angular to sub-rounded at the apex part (Fig. 3b).

\subsubsection{Structural-Denudational Units}

Among these units, the best developed are:

- Anticlinal ridges, which are well developed in Qamchuqa Formation (Fig. 2). Flat irons are also well developed in well bedded Kometan Formation and the upper part of Qamchuqa Formation (Figs. 2 and 4);

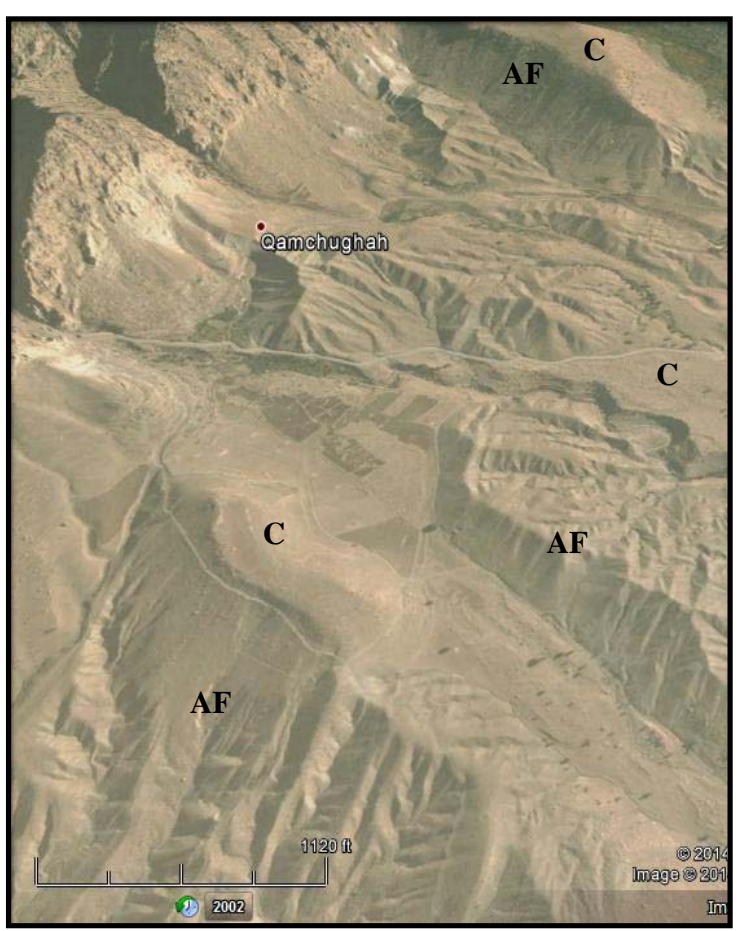

(b)

Fig. 2 Google Earth image: (a) series of alluvial fans forming bajada, along Pera Magroon and Surdash anticlines; (b) calcrete capping alluvial fans, part of the calcrete is already dissected by dense rills (both images are facing SW, SA: surdash anticline; PMA: Pera Magroon anticline; QQV: Qash Qooly valley; C: Calcrete; AF: alluvial fan; and DL: divide line between the two valleys). 

Using Exposure Age Determination Method

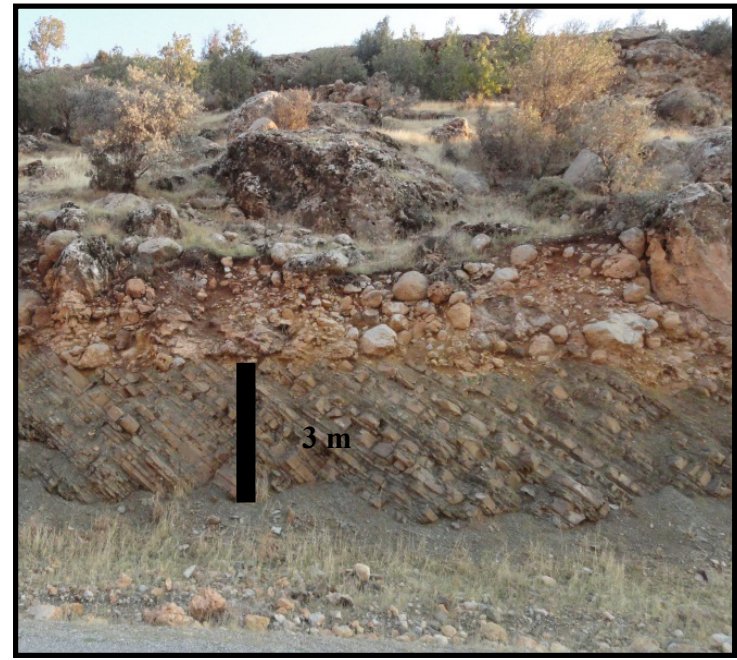

(a)

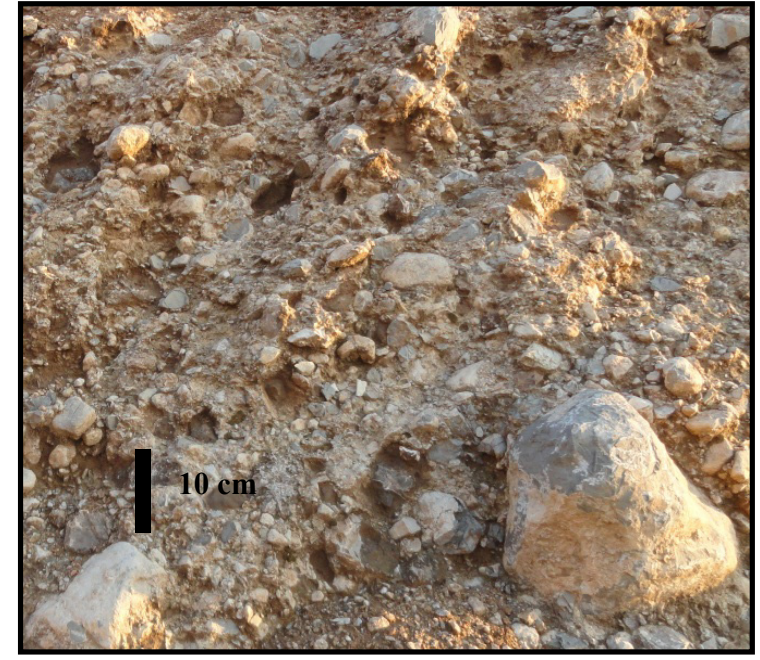

(b)

Fig. 3 Sediments of Zewe alluvial fan: (a) apex area; (b) proximal area.

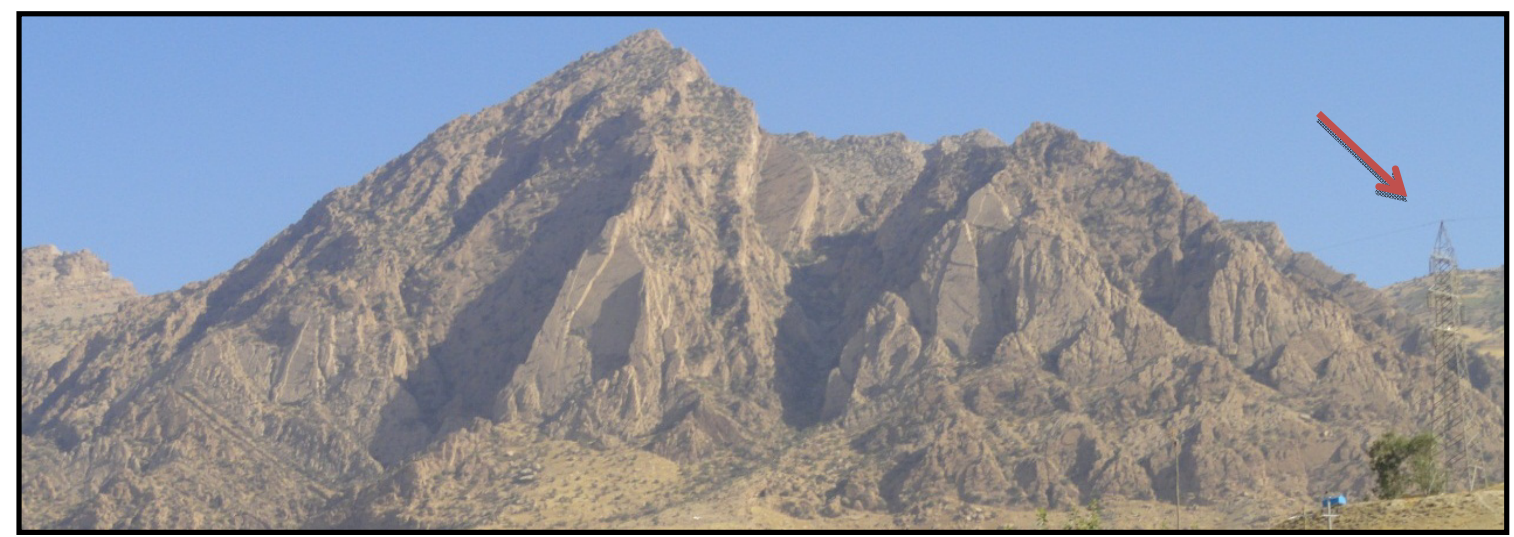

Fig. 4 Giant flat irons within the Qamchuqa Formation in Surdash anticline, comparing the size with the height of the tension tower, right of the photo.

- Dissected slopes are well developed within all exposed formations in Pera Magroon and Surdash anticlines (Figs. 1 and 2). Locally, bad land form is developed, too, when the drainage is densely dissected, then a flat and undulated plains form (Fig. 2).

\subsection{Tectonic Structure}

The area studied is located within the high folded zone of the unstable shelf $[9,10]$. However, according to Fouad [11], it is located within the outer platform, which belongs to the Arabian Plate. The high folded zone is characterized by NW-SE trending long and narrow anticlines separated by shallow and wide synclines. The southwestern limb of the anticlines in the area studied is steeper, as compared to the northeastern one. Locally, the southwestern limb is very steep, vertical and even overturned. Many faults of different types dissect the beds.

\subsection{Stratigraphy}

The exposed geological formations in the area studied range in age from Jurassic to Eocene $[5,6,8]$ (Fig. 5). The exposed formations in the valley are briefly described hereinafter:

- Sarmord Formation (Early Cretaceous): The formation consists of soft marl interbedded with hard limestone, dolomitic limestone and dolomite. The formation is a good source for supplying of sediments to the alluvial fans, calcrete, pediments, and the thickness of the formation is about $300 \mathrm{~m}$;

- Qamchuqa Formation (Early Cretaceous): The formation consists of thickly well bedded to massive, 


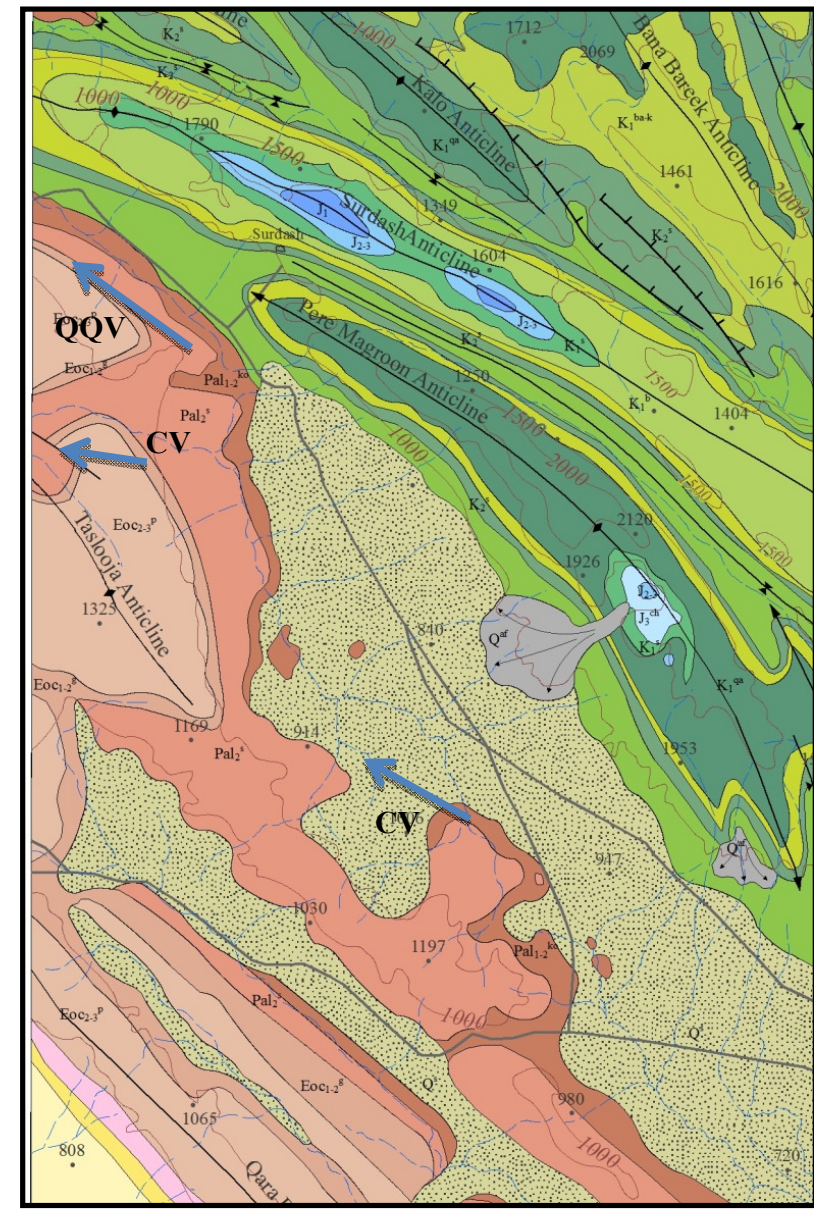

\begin{tabular}{|c|c|}
\hline \multicolumn{2}{|l|}{ Paleogene } \\
\hline Oli & $\begin{array}{l}\text { Oligocene (undifferentiated) } \\
\text { Thickly well bedded limestone }\end{array}$ \\
\hline $\operatorname{Eoc}_{2-3^{p}}{ }^{p}$ & $\begin{array}{l}\text { Pila Spi Formation } \\
\text { Limestone and marl with chert nodules, locally interfingering } \\
\text { with Avana Formation }\end{array}$ \\
\hline $\operatorname{Eoc}_{1-2^{8}}$ & $\begin{array}{l}\text { Gercus Formation } \\
\text { Alternation of red claystone, sandstone and rare conglomerate }\end{array}$ \\
\hline $\mathrm{Pal}_{2}{ }^{\mathrm{s}}$ & $\begin{array}{l}\text { Sinjar Formation } \\
\text { Well bedded limestone }\end{array}$ \\
\hline $\mathrm{Pal}_{1-2}{ }^{\mathrm{ko}}$ & $\begin{array}{l}\text { Kolosh Formation } \\
\text { Dark grey and black claystone, shale, siltstone with rare conglomerate }\end{array}$ \\
\hline \multicolumn{2}{|l|}{ Mesozoic } \\
\hline $\mathrm{K}_{2}^{\mathrm{t}}$ & $\begin{array}{l}\text { Tanjero Formation } \\
\text { Khaki colored shale, mudstone, sandstone and conglomerate, }\end{array}$ \\
\hline $\mathrm{K}_{2}^{\mathrm{s}}$ & $\begin{array}{l}\text { Shiranish Formation } \\
\text { Bluish grey marl and marly limestone }\end{array}$ \\
\hline $\mathrm{K}_{1}{ }^{\mathrm{k}}$ & $\begin{array}{l}\text { Kometan Formation } \\
\text { Well bedded white limestone }\end{array}$ \\
\hline $\mathrm{K}_{1}^{q^{\mathrm{aa}}}$ & $\begin{array}{l}\text { Qamchuqa Formation } \\
\text { Massive dolostone and limestone }\end{array}$ \\
\hline $\mathrm{K}_{1}^{\mathrm{ba-k}}$ & $\begin{array}{l}\text { Balambo and Kometan formations } \\
\text { Well bedded, white, hard limestone }\end{array}$ \\
\hline $\mathrm{K}_{1}{ }^{\mathrm{b}}$ & $\begin{array}{l}\text { Balambo Formation } \\
\text { Limestone, with yellow marl }\end{array}$ \\
\hline $\mathrm{K}_{1}^{\mathrm{s}}$ & $\begin{array}{l}\text { Sarmord Formation } \\
\text { Limestone with marl }\end{array}$ \\
\hline $\mathrm{J}_{3}{ }^{\text {ch }}$ & $\begin{array}{l}\text { Chia Gara Formation } \\
\text { Limestone with marl and shale }\end{array}$ \\
\hline $\mathbf{J}_{2-3}$ & $\begin{array}{l}\text { Barsarin, Naokelekan and Sargelu Formations } \\
\text { Mainly bedded to massive dolostone, limestone and marl }\end{array}$ \\
\hline $\mathbf{J}_{1}$ & $\begin{array}{l}\text { Sehkaniyan and Sarki Formations } \\
\text { Mainly limestone, dolostone, thinly bedded limestone and shale }\end{array}$ \\
\hline
\end{tabular}

Fig. 5 Geological map of the studied area [6] (CV: Charmaga valley; QQV: Qash Qooly valley).

very hard dolomite and dolomitic limestone. The formation is the main source for supplying the sediments of the alluvial fans, calcrete, pediments, and river terraces. The thickness of the formation ranges from $350 \mathrm{~m}$ to $950 \mathrm{~m}$;

- Kometan Formation (Early Cretaceous): The formation consists of thinly well hard and white limestone, slightly marly. The formation is a good source for supplying the fine and medium sized particles of the sediments of the alluvial fans, calcrete, pediments, and river terraces. The thickness of the formation ranges from $150 \mathrm{~m}$ to $175 \mathrm{~m}$;

- Shiranish Formation (Late Cretaceous): The formation consists of thinly well bedded blue marl and light grey limestone, in the lower part, whereas the upper part consists of fine clastics with very thin beds of limestone. The formation is a good source for supplying the fine and medium sized particles of the sediments of the alluvial fans, calcrete, pediments, and river terraces. The thickness of the formation ranges from $200 \mathrm{~m}$ to $250 \mathrm{~m}$;

- Tanjero Formation (Late Cretaceous): The formation consists of fine clastics, olive green in color. The formation is a good source for supplying the fine sized particles of the sediments of the alluvial fans, calcrete, pediments, valley terraces, and infill valley sediments. The thickness of the formation ranges from $800 \mathrm{~m}$ to $1,000 \mathrm{~m}$;

- Kolosh Formation (Paleocene): The formation consists of black fine clastics with very thin beds of conglomerate. The formation consists of soft rocks which are a good source for Quaternary sediments supply. The thickness of the formation ranges from $110 \mathrm{~m}$ to $150 \mathrm{~m}$;

- Quaternary sediments: Different Quaternary sediments are developed on both banks of Qash Qooly 
valley, especially the right bank, among them are: river terraces, alluvial fan sediments, calcrete, slope sediments, flood plain and infill valley fill sediments. All have large thicknesses with vast areal extent.

\section{Qash Qooly Valley}

\subsection{Characterestics}

Qash Qooly valley now is $12.56 \mathrm{~km}$ in length which starts near Har Lock Khwara village and merges in the Lesser Zab River about $7 \mathrm{~km}$ downstream from Dokan dam (Fig. 2). The elevation in the starting area is about 900 m.a.s.l., whereas in merging area, it is about 400 m.a.s.l., which means the gradient of the valley in this part is $4 \%$. Qash Qooly valley, however, was originally a very long valley which is about $45.56 \mathrm{~km}$, as Thalweg. It was starting from the southeastern plunge of Pera Magroon anticline (Fig. 1), near Qlaw Bash village, now it is called Charmaga valley, starting from elevation of about 900 m.a.s.1.. It is blocked northwest of Dulkan village, forming a water divide between the two valleys (Point WD, Figs. 6 and 7), at elevation of 801 m.a.s.l., and is shifted northwestwards (Point $\mathrm{ChV}$ in Fig. 6) at elevation of 672 m.a.s.1.. The gradient of Charmaga valley is $0.7 \%$, whereas, before the blockage, it was $1.1 \%$.
The valley is a strike valley, which is developed by vertical active erosion and mass wasting processes. This development is parallel to the strike of the soft and erosion resistant day-lighting limestone hard strata. All the beds are dipping toward southwest, and the amount of the dip is variable and ranges between $15^{\circ}$ to $45^{\circ}$, which is corresponding to the beds of Eocene and Early Cretaceous formations, respectively (Fig. 8). The low and high dip degrees belong to the strata that are located on the lower limb and on the core of the anticlines, respectively. The valley is located and developed on southwestern limb of the Pira Magroon (at the northeast) and Sara (at northwest of the valley) anticlines. The differential erosion is the main factor on the northeastern side of the valley, while the mass wasting is common on the southwestern side of the valley and is one of the factors that scoured the valley during Quaternary.

Most parts of the valley bottom are wide and consist of gently sloping plain (1 3/100) that is divided by Charmaga stream into two asymmetrical northeastern and southwestern parts. The former is wider and slopes toward the southwest. It is located at the foot of Pira Magroon Mountain, the Dokan town and Sulaimaniyah main road that pass through this

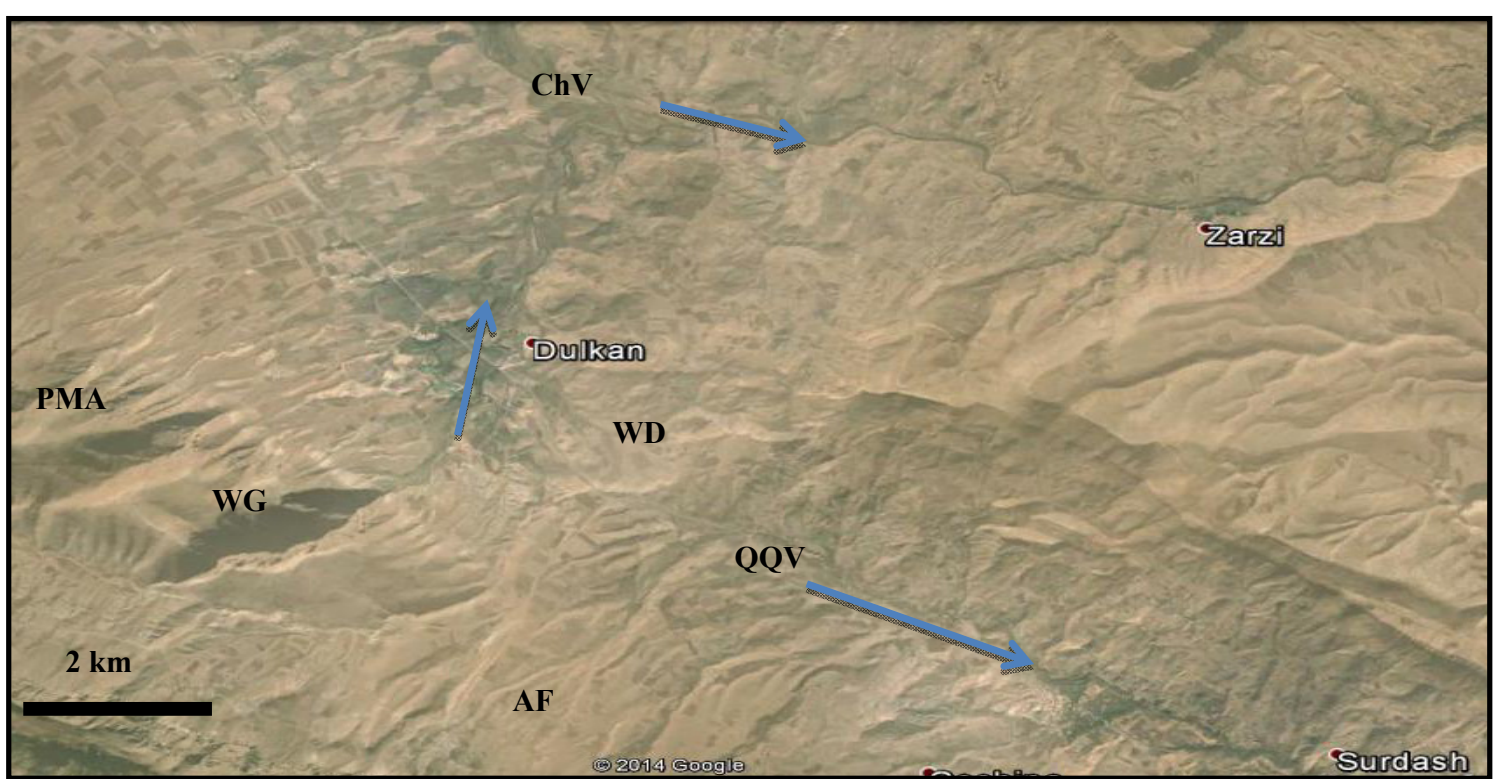

Fig. 6 Google Earth image (facing south, QQV: Qash Qooly valley; ChV: Charmaga valley; PMA: Pera Magroon anticline; WD: water divide area; WG: water gap; AF: alluvial fan). 


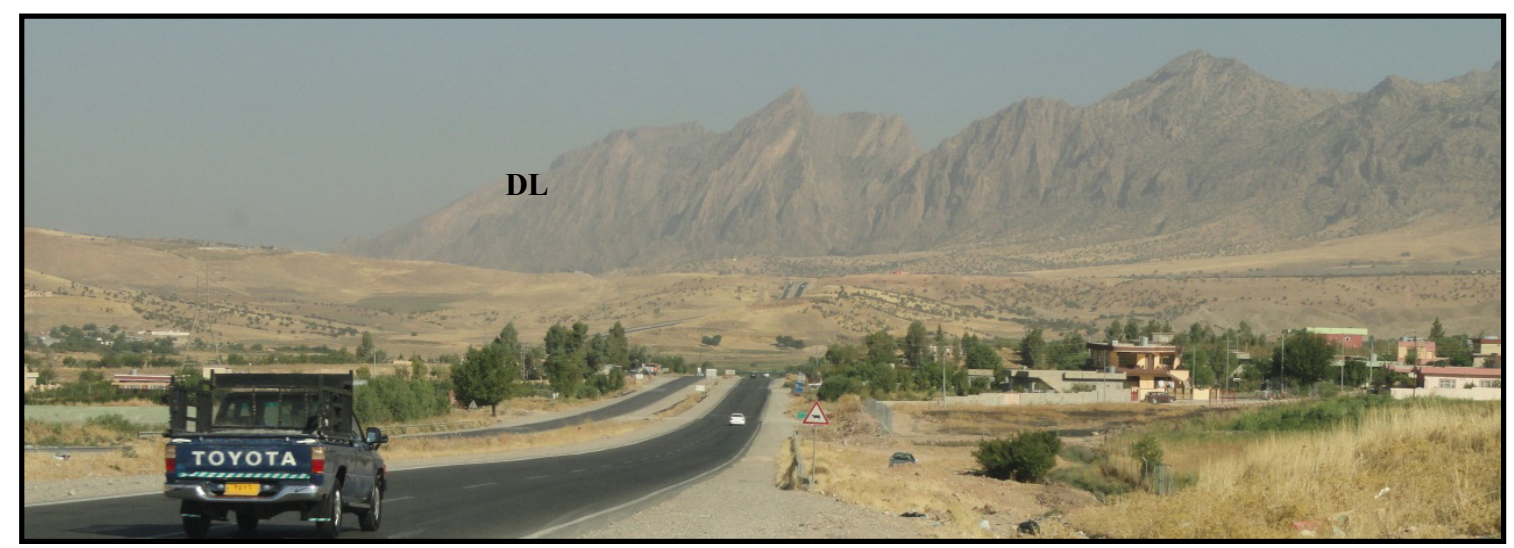

Fig. 7 The DL (divide line) between Qash Qooly and Charmaga valleys (note the developed alluvial fans along Surdash anticline).

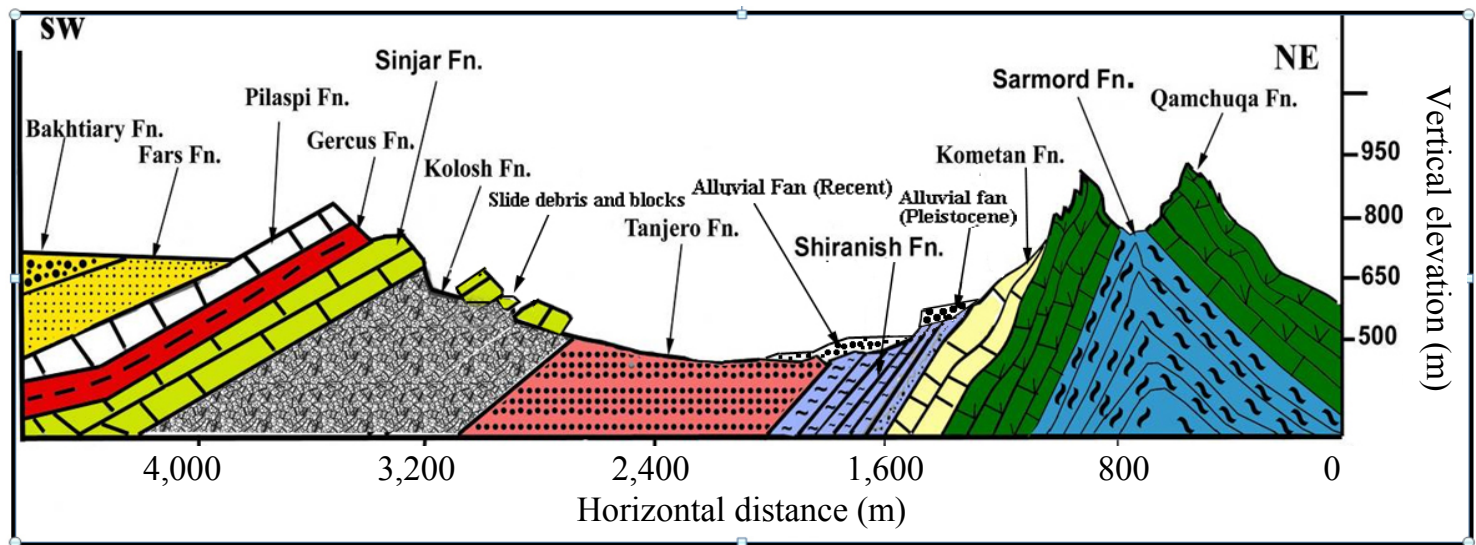

Fig. 8 Geological cross section across Pira Magroon anticline.

part. This part consists of a series of coalescing alluvial fans along a mountain front that form bajada (Figs. 2 and 6). These fan-shaped depositional terrains form the setting of sediments within a stream onto flat land at the foot of a mountain. The southwestern part at the valley bottom is narrow and is steeper than the former part, and both parts are dissected by tens of shallow consequent and obsequent ephemeral streams.

\subsection{Blockage of Qash Qooly Valley}

Qash Qooly valley was originally a long valley that includes the nowadays Qash Qooly and Charmaga valleys. The original valley was blocked due to continuous growth of many alluvial fans (Figs. 6, 7, 9 and 10) at the northwestern plunge area of Pera Magroon anticline (Figs. 2 and 6) [12]. Moreover, the lateral growth of Pera Magroon anticline also contributed in blocking of Qash Qooly valley, as it is evidenced from the development of the main water gap (WG in Fig. 6), which was abandoned and was changed to a wind gap due to the lateral growth of the anticline, but returned again as a water gap, after the blockage of the valley that was running north of Pera Magroon anticline and following its northwestern plunge (Fig. 9).

\section{Exposure Dating Method}

When traditional dating methods are not available, like paleontological studies, or accurate dating, like C14, exposure dating method can be used [7]. The method depends on many factors, which cannot be necessarily available at the same place where dating is required. Among the factors there are meandering of rivers [13] and mass movements, which are considered as the best methods for age estimation, besides the super position criterion, the factors are: (1) 


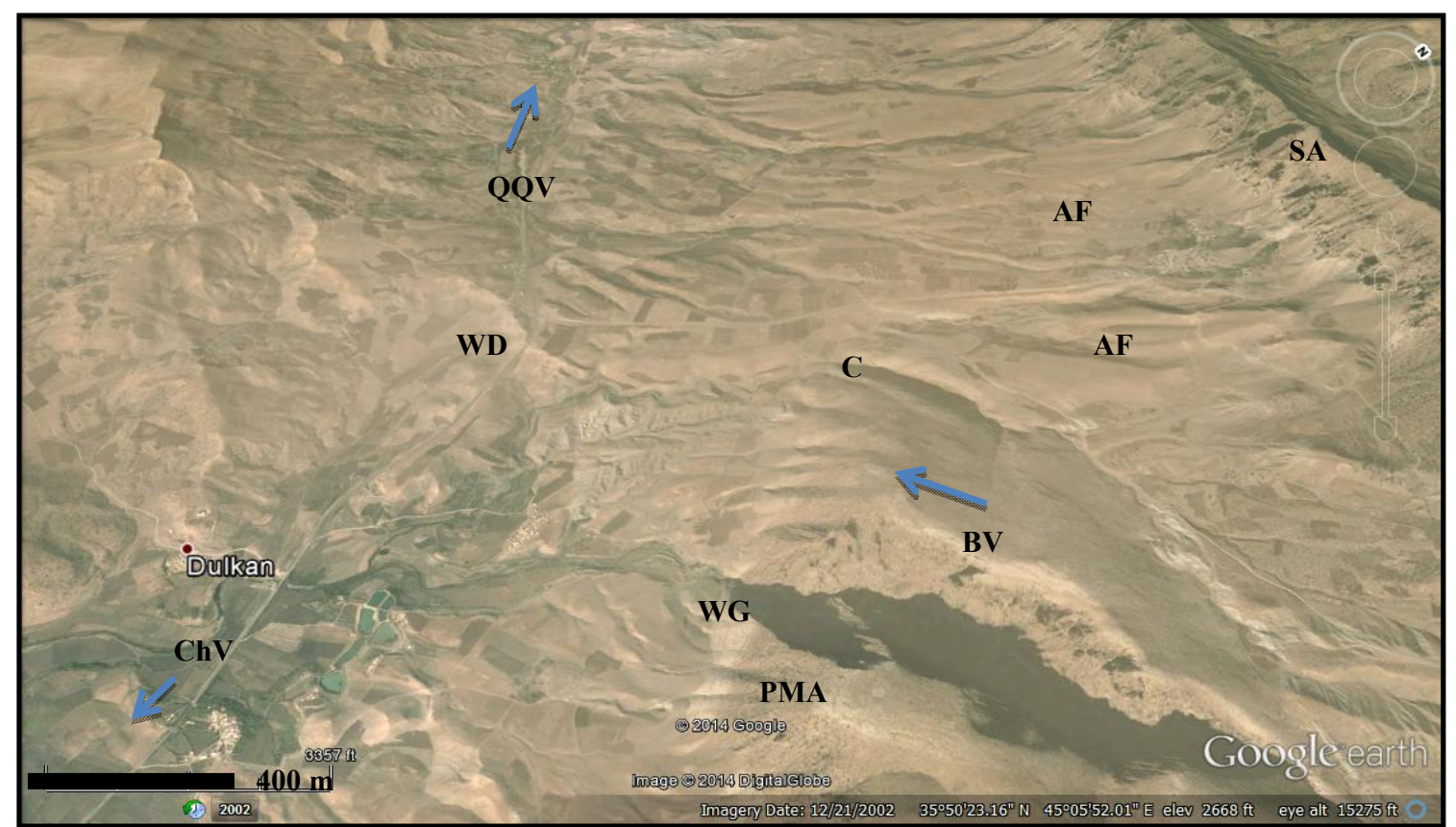

Fig. 9 Google earth image facing NE (WG: water gap; WD: water divide; QQV: Qash Qooly valley; BV: blocked valley; AF: alluvial fan; SA: Surdash anticline; PMA: Pera Magroon anticline; and ChV: Branch of Charmaga valley).

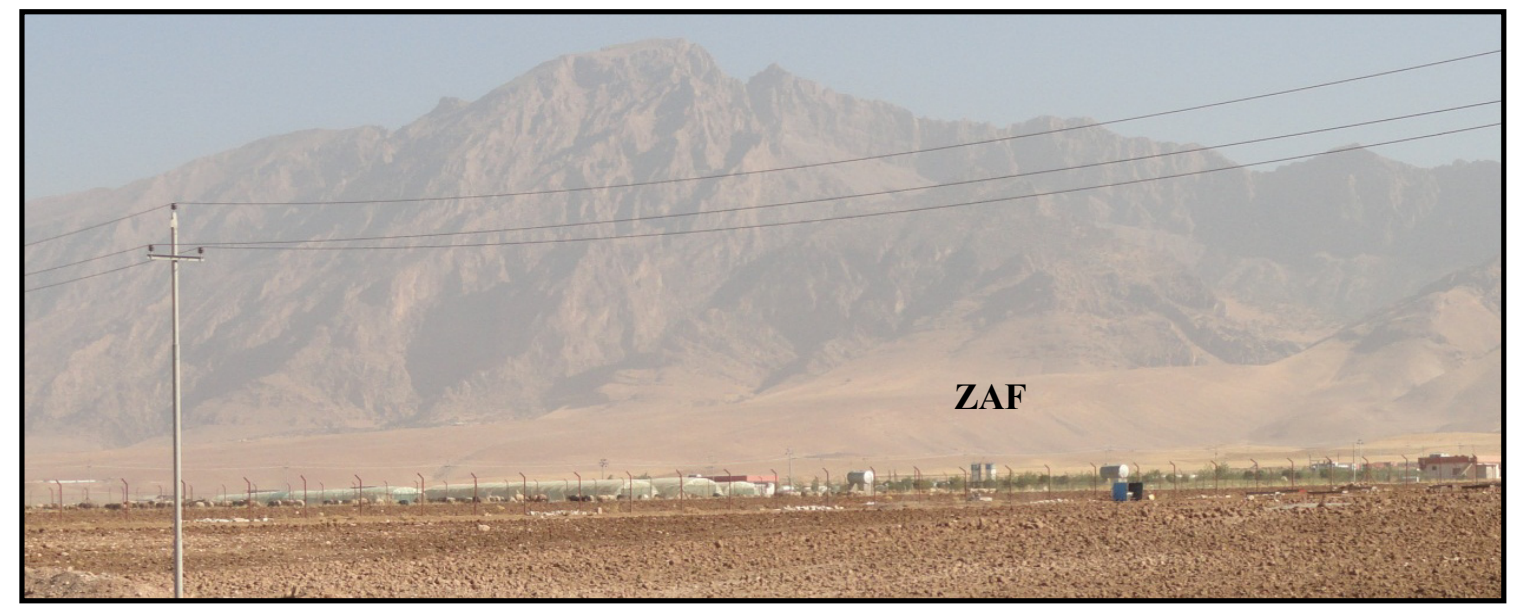

Fig. 10 One of the largest alluvial fans in the studied area (ZAF: Zewe alluvial fan).

presence or otherwise the location and/or traces of the crown, scar area, and the toe of a mass movement phenomenon; (2) presence of terraces, calcrete, alluvial fans next to the involved area; (3) presence or otherwise of the ancient river and/or stream course; (4) presence of other type(s) of mass movement, usually mud flow within the already slid mass; (5) presence of evidence(s) for active erosion in the involved area; and (6) size of valleys, including depth, width, length and terrace level(s) in the involved area.

In this study, many of the aforementioned factors were used successively to estimate the age of Qash Qooly valley and its blockage, which divided the valley into two valleys - called Qash Qooly and Charmaga valleys.

\section{Results}

The Qash Qooly valley was originally a long valley, about $45.56 \mathrm{~km}$, but it was divided near Dulkan village (Figs. 7 and 9) into two valley. The one to the south is called Charmaga valley. The reason of the divide is the continuous growth of many alluvial fans (Figs. 2, 
6, 7 and 9) near the northwestern plunge of Pera Magroon anticline, besides the lateral growth of the anticline. The blockage was during Late Pleistocene.

\section{Discussion}

\subsection{Deposition of the Alluvial Forms}

The basin in which Qash Qooly valley spreads includes thick alluvial sediments of different types.
The sediments are described hereinafter.

\subsubsection{Alluvial Fans}

Tens of alluvial fans are developed on the southwestern limbs of Pera Magroon (Fig. 11) and Surdash (Fig. 12) anticlines. Some of the alluvial fans have very large surface areas, with length reaching up to few kilometers like the Ziwi alluvial fan; with length of $5.75 \mathrm{~km}$ and that of Qamchuqa alluvial fan; with length of $4.65 \mathrm{~km}$.

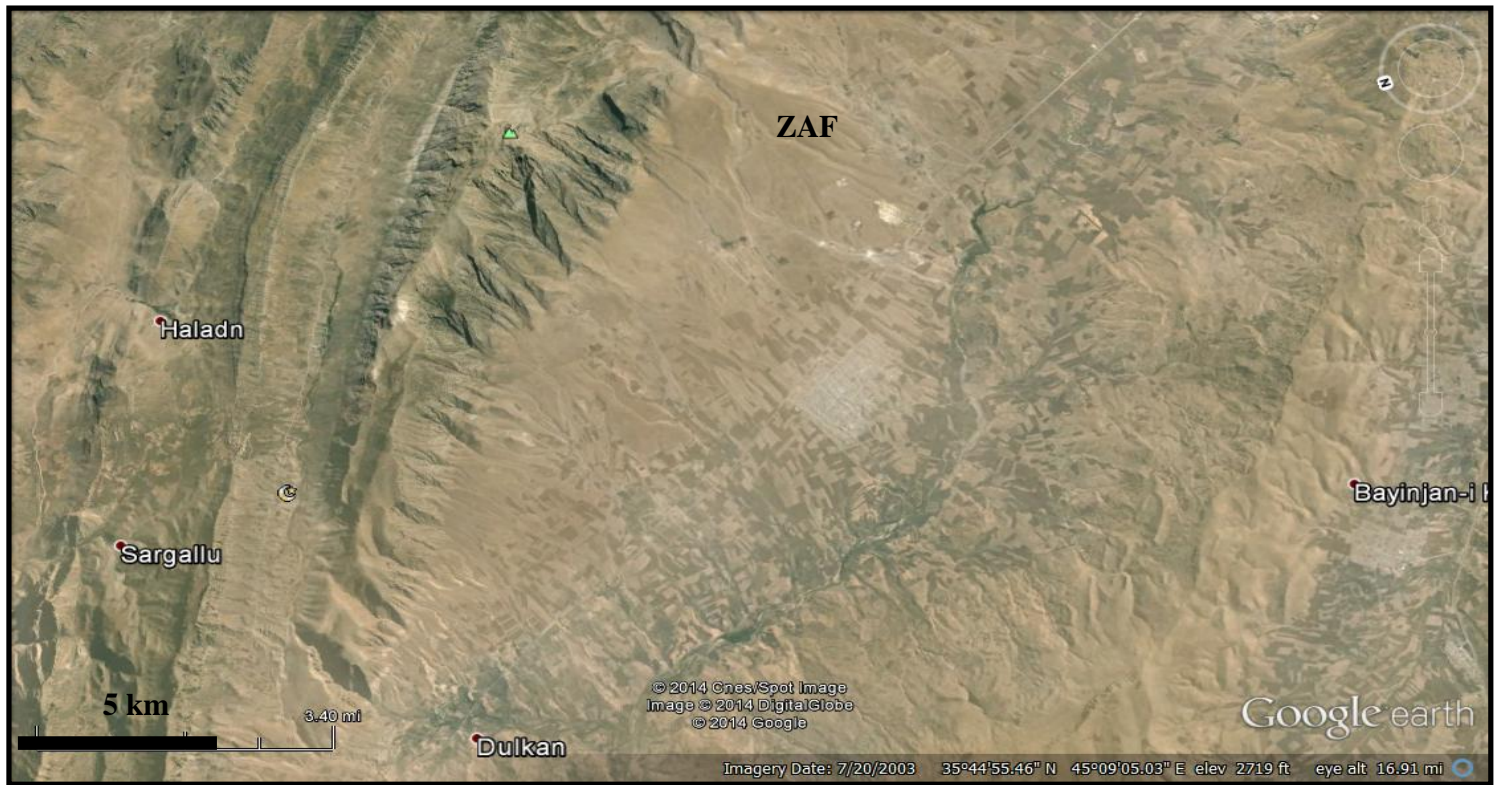

Fig. 11 Google Earth image (Facing NE) showing the developed alluvial fans along the southwestern limb of Pera Magroon anticline (ZAF: Zewe alluvial fan).

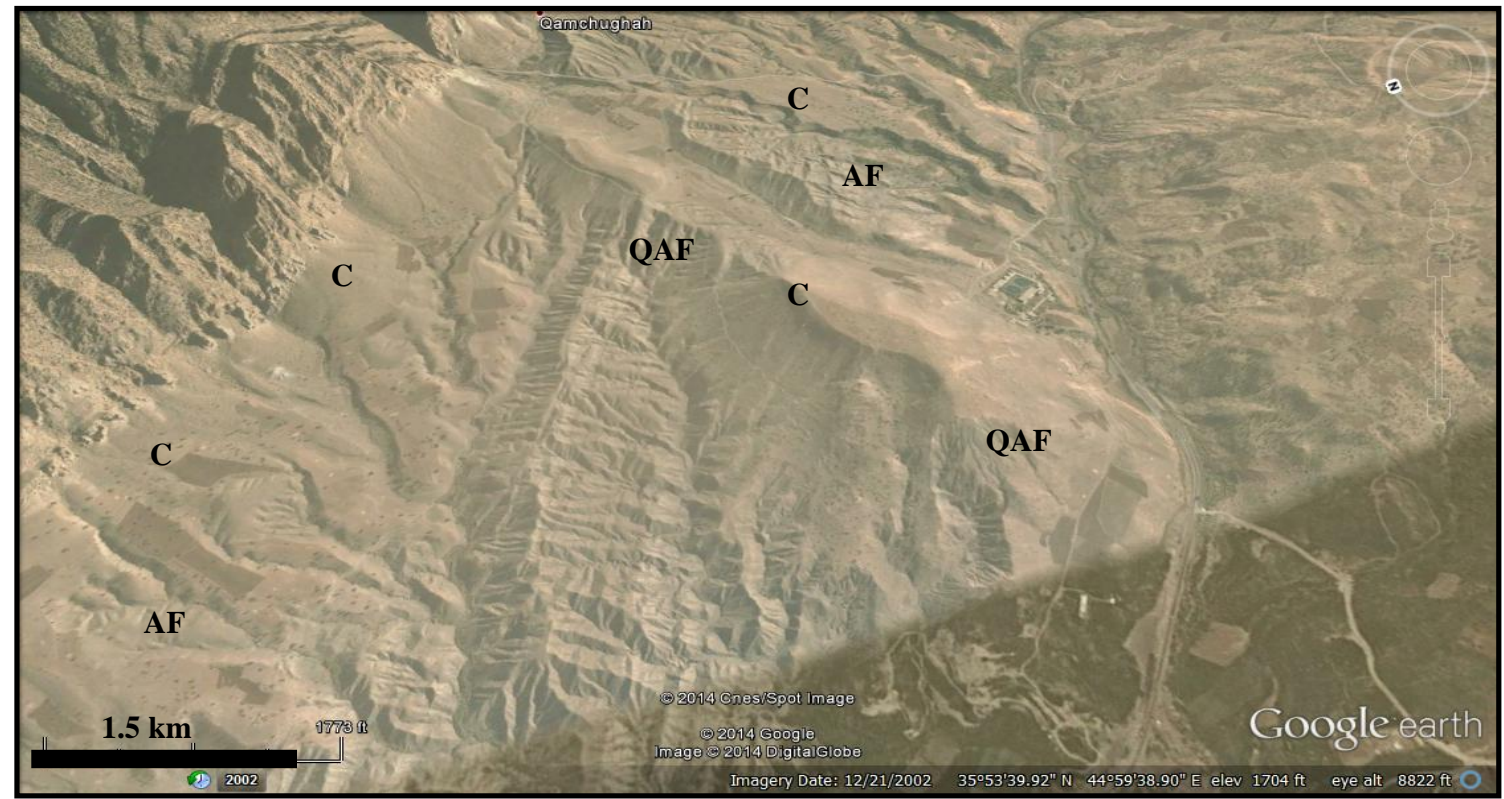

Fig. 12 Google Earth image (Facing NE) showing the developed alluvial fans along the southwestern limb of Surdash anticline (note the C (calcrete) caps all AF (alluvial fans), which started to be eroded, QAF: Qamchuqa alluvial fan). 


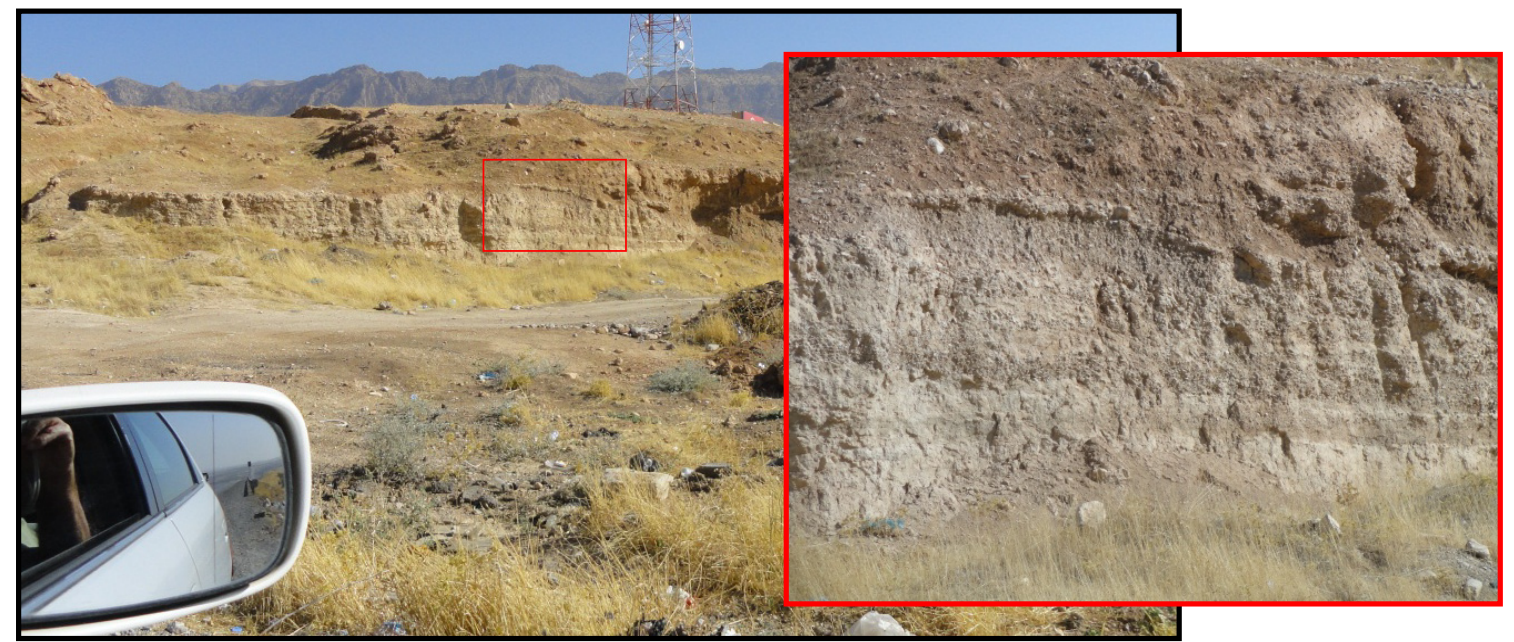

Fig. 13 Toe of an alluvial fan near Qamchuqa village (note the details in the enlarged caption).

The main constituents of the alluvial fans are derived from of the Qamchuqa Formation, and the pebbles are sub-rounded and rounded (Fig. 3), and the size differs from the distal part (Boulder size) to the toe of the fan $(1 \sim 10 \mathrm{~cm})$ (Fig. 13). The cement is calcareous materials with very fine clastics. The fan is capped by thick calcrete.

The alluvial fans were covering almost the majority of the basin, especially the nowadays right bank of Qash Qooly valley, although some boulders derived from the Qamchuqa Formation can be seen on the left bank of the valley, indicating their presence before development of the valley.

On the northeastern part of the valley, alluvial fans of Pleistocene age can be seen in many places like near Qamachuqa village (Fig. 12) and south of Zewe Gorge (Fig. 11). These fans are of Early Pleistocene age or even Pliocene, as majority of the alluvial fans in Iraq [4-6, 12-23] which are located at higher elevations, locally forming small plateaus. These fans are represented by gently inclined thick conglomerate, about $10 \mathrm{~m}$ thick, locally more. Their inclination is nearly equal to the local slope of the valley side which is about $15^{\circ}$. The thickness of the fan decreases towards the upper valley slope. The clasts size ranges from 2 200 cm, mostly rounded and badly sorted and cemented (lithified) by calcareous and sandy materials. The surface areas of these remnants are not more than few square kilometers.

The Holocene fans cover larger areas, as compared to Pleistocene fans, but with lesser thickness, and it is possible that they are mixed with valley terraces and/or infill valley sediments in their proximal parts. The clasts are not cemented (not lithified) and range in size from 2 30 cm, however, locally may exceed $1 \mathrm{~m}$. Lithologically, the clasts are derived from the Qamchuqa Formation with subordinate clasts derived from the Kometan Formation. These fans mainly occur on the northeastern part of the valley bottom.

\subsubsection{Calcrete}

Almost all Pleistocene fans are covered by calcrete with thickness ranges from 1 3 m. However, locally, the thickness reaches more than $5 \mathrm{~m}$, like in Zewe alluvial fan. The main constituent of the calcrete is derived from the Qamchuqa Formation, the clasts range in size from $1 \sim 30 \mathrm{~cm}$ (Fig. 14), and rarely may exceed $1 \mathrm{~m}$, mainly angular. The cement is calcareous materials with fine clastics forming very hard cement. The vast extension of the calcrete in the studied area (Figs. 2, 9 and 11) indicates that the whole area was covered by calcrete during the Pleistocene, consequently indicating wet phase. The calcrete cover, however, started to be disintegrated due to erosion by dense rills (Figs. 2, 9 and 11) leading the exposure of the alluvial fan sediments, which are less resistant to erosion, as compared to the calcrete. This means the 
division of Qash Qooly and Charmaga valleys is younger than the calcrete, because they and their branches started eroding the calcrete. The estimated age for the division is during the Late Pleistocene.

\subsubsection{Pediment}

Depositional pediment is widely developed in the studied area (Figs. 2, 9 and 10). They are also capped by calcrete and their constituent is almost similar to the alluvial fan sediments, with main difference that they lack any stratification, very poorly sorted and weakly cemented (Fig. 15). Some boulders of the Qamchuqa Formation, up to $1 \mathrm{~m}$ in size, can be seen on the left bank of Qash Qooly valley, especially opposite side of Qamchuqa gorge, indicating that the boulders were transformed to their nowadays locations before developing of the valley, otherwise the boulders would not be present on the left side.

Some of the pediments on the left bank of Qash Qooly valley (Fig. 16) show inclination towards the valley, which is a normal case. However, originally,

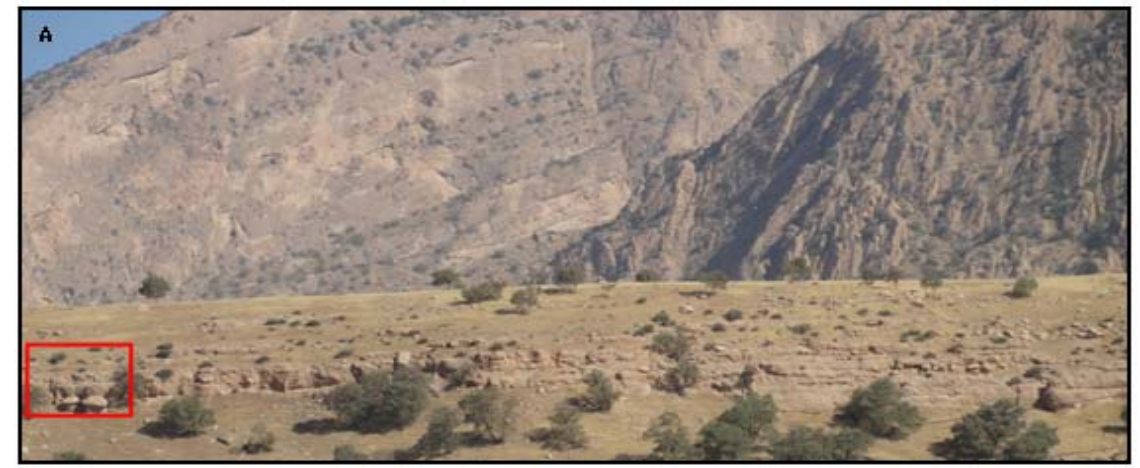

(a)
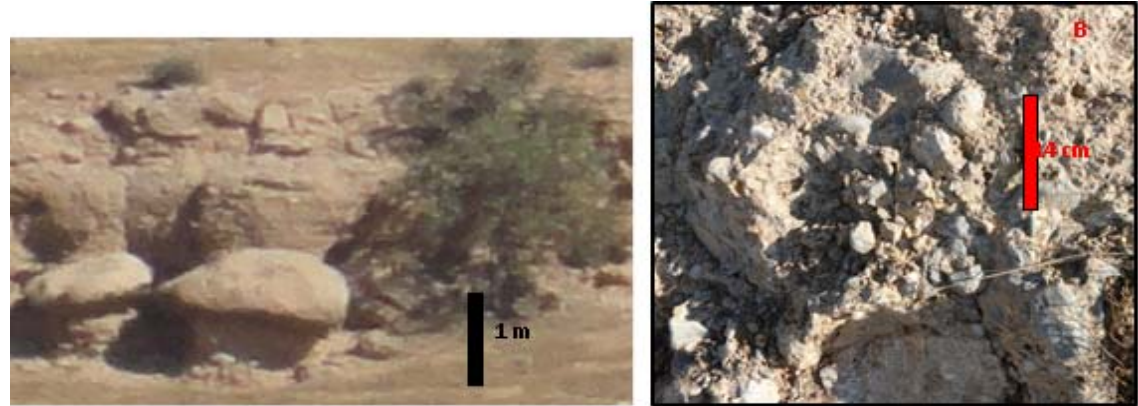

(b)

Fig. 14 (a) Calcrete capping Qamchuqa alluvial fan. Note the details in the caption. Compare the thickness of the calcrete with the height of the shrubs (about $1 \mathrm{~m}$ ); (b) calcrete in the top of Zewe alluvial fan, distal part.

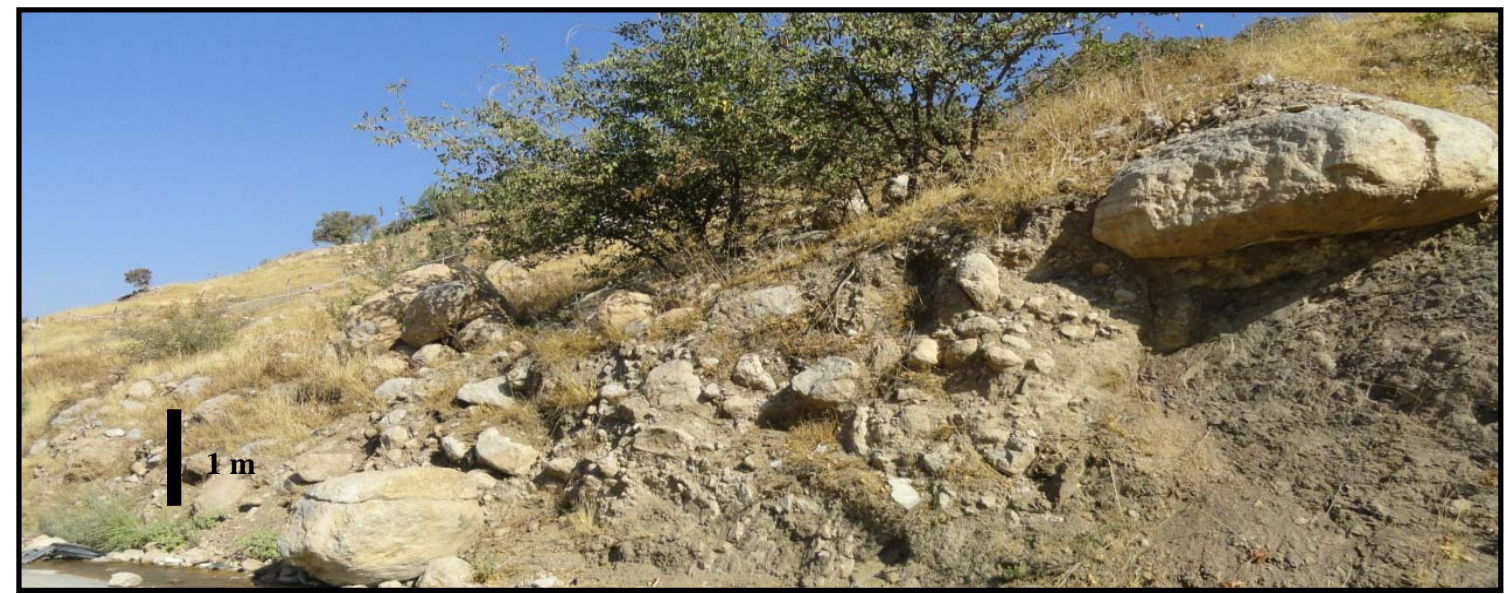

Fig. 15 Depositional pediment, near Qamchuqa village (note the poorly sorted sediments, lack of stratification and weak cementation). 


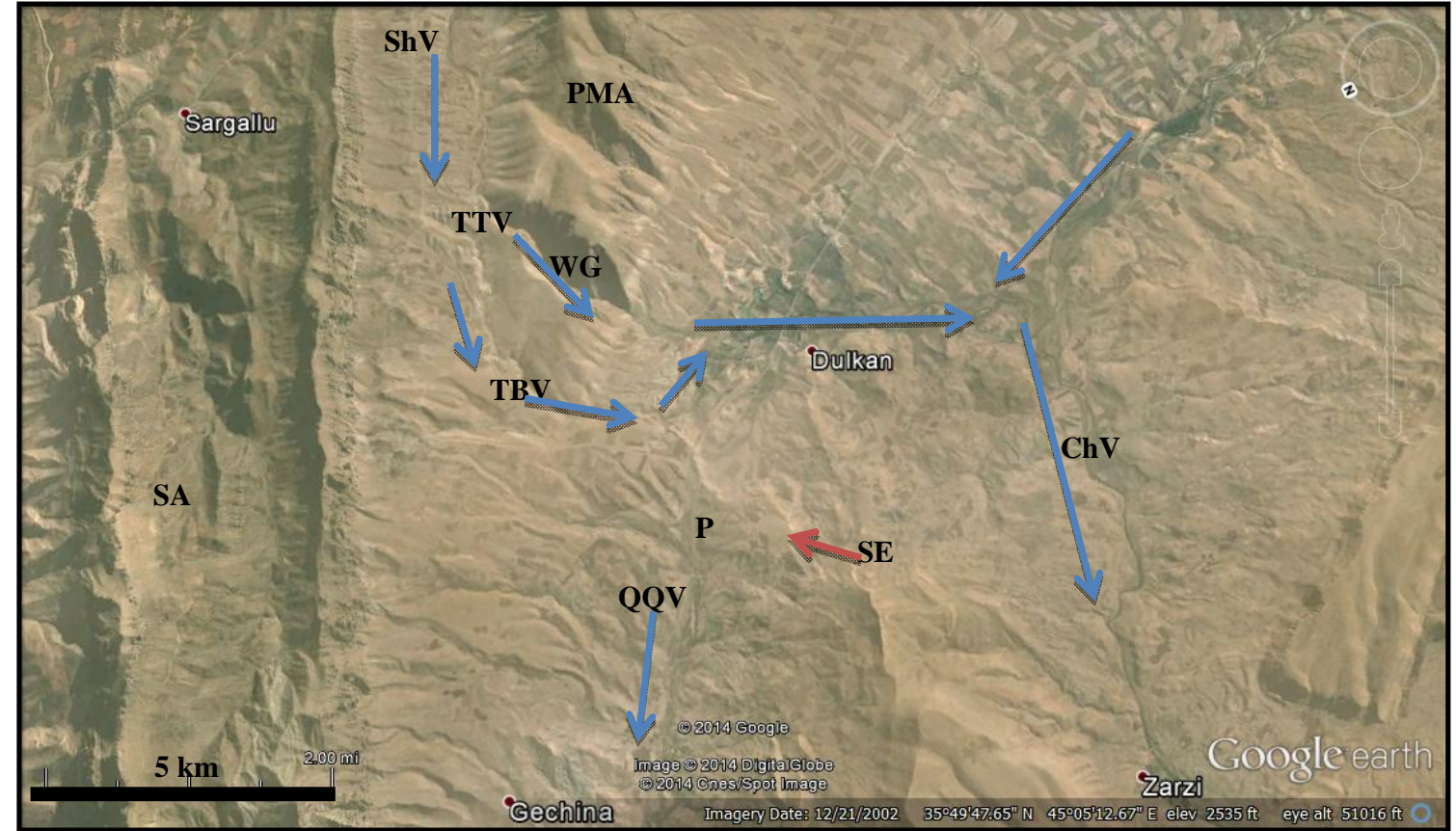

Fig. 16 Google Earth image facing southeast (note the continuation of the P (pediments) on the left bank of QQV (Qash Qooly valley), ChV: Charmaga; ShV: Shadla; TTV: Tang Taybeen; TBV: Taga Buchooka; WG: water gap; PMA: Pera Magroon anticline; and SA: Surdash anticline).

they were sloping off the valley, because they are originated from Shiranish, Kometan, Qamchuqa and Sarmord Formations, which are exposed on the right bank of the valley (Fig. 5) along the southwestern limbs of Pera Magroon, Sara and Surdash anticlines, but due to the erosion of Qash Qooly valley, they got inclination towards the valley (Fig. 16). Moreover, the southwestern toe of the pediment has sharp edge (point SE in Fig. 16), which is subjected to active erosion. If it was not the continuation of the pediment deposited from the southwestern limb of Surdash anticline, then it would not be isolated from the southwest looking cliff and being deposited so far distance from the cliff. This also means that the pediments are older than the valley.

\subsection{Blockage of Qash Qooly Valley}

As aforementioned, Qash Qooly valley was a long valley, but it was blocked. Therefore, it is divided into two parts (Figs. 7 and 16). The blockage of the valley has the following scenario (Fig. 16): (1) Shadla valley was flowing parallel to Pera Magroon anticline and crossing it from its southwestern plunge area (at area marked as WG); (2) After the lateral growth of Pera Magroon anticline, the valley was shifted northwest ward and the crossing at WG area was abandoned and changed to a wind gap (as defined by Keller and Pinter [7]); (3) With continuous lateral growth of Pera Magroon anticline and continuous growth of the alluvial fans, northwest wards of the plunge area, Shadla valley was blocked [12]; (4) Shadla valley was shifted its course and returned to the abandoned wind gap to be the new crossing across Pera Magroon anticline forming Tang Taybeen valley as a water gap again; (5) Later on, the remaining part of Shadla valley with some small branches re-crossed Pera Magroon anticline from its northwestern plunge area, forming Taga Buchooka valley; (6) The lateral growth of Pera Magroon anticline and the alluvial fans have raised the area, northwest of Dulkan village, consequently blocking Qash Qooly valley and dividing it into two parts, the other one is called Charmaga valley.

There is no other explanation to the presence of the raised area, northwest of Dulkan village, which has blocked Qash Qooly valley and was dividing it into 
two parts. It is worth mentioning that structurally the plunge area of an anticline always forms topographic lower area, which contradicts the present situation. Therefore, the only explanation for the presence of the raised area, near to the northwestern plunge of Pera Magroon anticline, is the aforementioned scenario.

Near Qamchuqa village, on the right bank of the valley, thick sediments, up to $15 \mathrm{~m}$, are developed starting almost from the valley floor. They include infill valley and flood plain sediments, which are partly mixed with the pediment and Holocene alluvial fan sediments. These sediments would not be deposited in such huge thickness unless the valley was very large (long) valley, otherwise the thickness should be much less than the recorded thickness.

\subsection{Dating of the Valley}

Qash Qooly valley is an old and large valley, most probably of Early Pleistocene in age and possibly older, Pliocene, as evidenced from the presence of the large alluvial fans, with boulders of the Qamchuqa Formation on its left bank, and thick flood plain sediments, up to $15 \sim 20 \mathrm{~m}$ thick. The valley was blocked by the lateral growth of Pera Magroon anticline and alluvial fans during Late Pleistocene to Early Holocene, as evidenced by the presence of thick calcrete on the top of the divide area, which forms the nowadays water divide between Qash Qooly and Charmaga valleys (Fig. 16). However, Qash Qooly valley is still suffering from the growth of Qamchuqa alluvial fan (Fig. 12), as it is clear from the developed meander on its course in the proximal part of the fan.

\section{Conclusions}

Qash Qooly valley runs parallel to Pera Magroon, Sara and Surdash anticlines, almost in SE-NW trend, and merges with the Lesser Zab River $9 \mathrm{~km}$ southeast to Dokan town. Its width, depth and length are $2 \mathrm{~km}$, $500 \mathrm{~m}$ and $12.6 \mathrm{~km}$, respectively. The valley runs within the soft rocks of Shiranish, Tanjero and Kolosh formations, forming badland morphology, whereas on the extreme right side, Shiranish, Kometan and Qamchuqa formations are exposed. Towards northeast of the valley, the slopes along the southwestern limbs of Pera Magroon, Sara and Surdash anticlines are mainly covered by thick Quaternary sediments. The sediments are in form of alluvial fans, piedmonts and calcrete, with local terraces of the valley. The present length of the valley is $12.56 \mathrm{~km}$, whereas originally, it was about $46 \mathrm{~km}$. Near the northwestern plunge of Pera Magroon anticline, the valley was blocked by large alluvial fans, leading to the division of the valley in two valleys. The small one is Qash Qooly, whereas the large one is called Charmaga valley, which has the same trend but is shifted towards northwest. The alluvial fan sediments, piedmont and calcrete are very well developed with huge thicknesses that exceed $30 \mathrm{~m}$. The sediments include boulders up to $2 \mathrm{~m}$ in size, sub-rounded to rounded. However, the average size of the pebbles ranges from 15 45 cm, derived mainly from the Qamchuqa formation (Early Cretaceous). The sediments are well cemented, usually capped by calcrete. Locally, bellow the calcrete, there is terra rosa, reddish brown, hard and well compacted. The calcrete and even the alluvial fans have almost flat tops, which slope towards the valley. Locally, the top sediments are dissected by dens net of rills.

Present research indicated that Qash Qooly and Charmaga valleys were originally one long valley. The valley was divided into two parts by means of the lateral growing of Pera Magroon anticline and the alluvial fans in the north western plunge area of the anticline.

The lateral growth of Pera Magroon anticline is indicated by the presence of a water gap, which was originally the passage of Tan Taybeen valley, then was changed to a wind gap, due to the lateral growth, and then was returned to a water gap after the blockage of the valley. The age of Qash Qooly valley is Early Pleistocene, whereas its blockage and division into two parts was most probably during the Late 
Pleistocene to Holocene.

\section{Acknowledgments}

The author would like to thank Prof. Dr. Kamal H. Karim (University of Sulaimani) for his contribution in the field work and valuable comments that helped in the amending of this article.

\section{References}

[1] Hamasur, G. A. 1992. "The Quantitative Analysis of the Qara Chattan Rock Slide from Northeastern Iraq." Journal of Dohuk University 2: 465-76.

[2] Hamza, N. M. 1997. Geomorphological Map of Iraq, Scale 1:1,000,000. Baghdad: Iraq Geological Survey.

[3] Karim, K. H., Hamasur, G. A., and Tofiq, S. M. 2000. "Qara-Chatan Rockslide in Pira-Magroon Anticline, Northeastern Iraq.” Journal of Zankoy Sulaimani 3 (1): 33-47.

[4] Barwari, A. M., Yacoub, S. Y., and Buni, T. J. 2003. Quaternary Sediments Map of Iraq, Scale 1:1,000,000. Baghdad: Iraq Geological Survey.

[5] Sissakian, V. K., and Fouad, S. F. 2012. Geological Map of Iraq, Scale 1:1,000,000. 4th ed.. Baghdad: Iraq Geological Survey.

[6] Sissakian, V. K., and Fouad, S. F. 2014. Geological Map of Sulaimaniyah Quadrangle, Scale 1:250,000. 2nd ed.. Baghdad: Iraq Geological Survey.

[7] Keller, E. A., and Pinter, N. 2002. Active Tectonics, Earthquakes, Uplift and Landscape. 2nd ed.. New Jersey: Prentice Hall.

[8] Al-Shiwaily, A. K., Al-Mosawi, H. K., Al-Saffi, I. K., Bashir, W. P., Ibrahim, A. A., Al-Jubouri, B. S., et al. 2011. Semi Detailed Geological Mapping of Sulaimaniyah-Surdash Area. Baghdad: Iraq Geological Survey.

[9] Al-Kadhimi, J. A. M., Sissakian, V. K., Sattar, A. F., and Deikran, D. B. 1997. Tectonic Map of Iraq, Scale 1:1,000,000. 2nd ed.. Baghdad: Iraq Geological Survey.

[10] Jassim, S. Z., and Goff, J. C. 2006. Geology of Iraq. UK: Geological Society of London.
[11] Fouad, S. F. 2012. Tectonic Map of Iraq, Scale 1:1,000,000. 3rd ed.. Baghdad: Iraq Geological Survey.

[12] Sissakian, V. K., and Jabbar, M. F. A. 2010. "Morphometry and Genesis of the main Transversal Gorges in North and Northeast Iraq." Iraqi Bulletin of Geology and Mining 6 (1): 95-120.

[13] Sissakian, V. K., Shihab, A. T., Al-Ansari, N., and Knutsson, S. 2014. "Al-Batin Alluvial Fan, Southern Iraq.” Engineering 6: 699-711. Accessed October 30, 2014. http://dx.doi.org/10.4236/3ng.2014.61.

[14] Yacoub, S. Y. 2011. "Geomorphology. In: Geology of Mesopotamia Plain.” Iraqi Bulletin of Geology and Mining 4: 47-82.

[15] Yacoub, S. Y., Othman, A. A., and Kadhum, T. H. 2011. "Geomorphology. In: Geology of the Low Folded Zone." Iraqi Bulletin Geology Mining 5: 7-38.

[16] Sissakian, V. K. 2011. "Alluvial Fans of Sinjar Mountain, NW Iraq.” Iraqi Bulletin Geology Mining 7 (2): 9-26.

[17] Sissakian, V. K. 2013. "Geomorphology and Morphometry of the Greater Zab River Basin, North of Iraq.” Iraqi Bulletin Geology Mining 9 (3): 21-49.

[18] Sissakian, V. K. 2013. "Geological Evolution of the Iraqi Mesopotamia Foredeep and Inner Platform, and Near Surrounding Areas of the Arabian Plate." Journal of Asian Earth Sciences 72: 152-63.

[19] Sissakian, V. K., and Jabbar, M. F. A. 2013. "The Alluvial Fans of Habbariyah Depression, Iraqi Western Desert.” Iraqi Bulletin Geology Mining 9 (2): 27-45.

[20] Sissakian, V. K., and Fouad, S. F. 2014. Geological Map of Kirkuk Quadrangle, Scale 1:250,000. 2nd ed.. Baghdad: Iraq Geological Survey.

[21] Sissakian, V. K., and Fouad, S. F. 2014. Geological Map of Erbil and Mahabad Quadrangles, Scale 1:250,000. 2nd ed.. Baghdad: Iraq Geological Survey.

[22] Sissakian, V. K., Kadhum, T., and Jabbar, M. F. A. 2014. "Geomorphology. In: Geology of the High Folded Zone." Iraqi Bulletin Geology Mining 6: 7-56.

[23] Sissakian, V. K., Jabbar, M. F. A., Al-Ansari, N., and Knutson, S. 2014. "Meandering of Tributaries of the Tigris River Due to Mass Movements, within Iraq." Journal of Engineering 6: 712-30. 